acceptable - the convulsions or the toxic effects. If extrapyramidal movements do in fact represent toxic damage to the cerebellum it would seem advisable to us to discontinue phenytoin in such a case and substitute one of the other drugs in the steadily expanding anticonvulsant armamentarium.-We are, etc.

\section{H. BeLlMAN}

Exeter

L. HAAS

\section{Pharaoh's Ants in Hospitals}

SIR,-Further to Mr. P. L. G. Bateman's letter (18 May, p. 383) I have found the most successful means of getting rid of ants is just to pour boiling water down their point of entry, whether it be a hole or crack. After one or two applications there is no more trouble.-I am, etc.

Bodmin, Cornwall

Q. M. ADAMS

\section{Tunnel Tactics}

SIR,-It was with interest that I read your leading article on carpal tunnel syndrome (15 June, p. 573). In particular, I note the reference to the presence of forearm and upper arm symptoms in nearly $60 \%$ of Cherrington's cases. 1 Later, the statement that "coincident clinical and radiographic evidence of cervical spondylosis is common" is made and symptoms caused by root irritation are said to be distinguishable from those of carpal tunnel syndrome on the clinical grounds of difference in pain distribution and a relationship to head and neck movement. Such a distinction may not always be possible.

Upton and $\mathrm{McComas}^{2}$ propose that an insult to peripheral nerves occurring both in the neck and at the wrist might predispose to the development of carpal tunnel syndrome by a "double crush" mechanirm. They provide electro-physiological evidence that $70 \%$ of their 115 patients with carpal tunnel syndrome also had cervical root lesions. Patients had deliberately not been excluded from their series on the basis of neck or upper arm pain. The work of Crymble $^{3}$ again suggests that carpal tunnel syndrome and cervical root lesions cannot be clearly distinguished on the basis of pain distribution. Patients with prominent proximal symptoms at least merit a complete electro-physiological investigation if not decompression at both the neck and wrist.-I am, etc.,

Department of Medicine,

J. ScotT

General Hospital

Birmingham

1 Cherington, M., Archives of Surgery, 1974, 108, 2 Upton, A. R. M., and McComas, A. J., Lancet, 1973, 2, 359.

3 Crymble, B., British Medical fournal, 1968, 3,

\section{Hypotension with Intravenous Salbutamol} in Premature Labour

SIR,-During the course of administering salbutamol intravenously in patients with premature labour ${ }^{1}$ we came across a side effect not previously noted. ${ }^{2}$ A total of 32 patients have been treated so far. Salbutamol $25 \mathrm{mg}$ was administered in $500 \mathrm{ml}$ of $5 \%$ dextrose starting at 10 drops per minute using an ordinary intravenous infusion set. The dose was increased by 10 drops per minute every 10 minutes till 40 drops per minute was reached or the patient's pulse rate increased to 140 per minute or the oontractions ceased, whichever occurred earlier

The results so far are similar to those of Liggins and his colleagues ${ }^{2}$ with one excepion. Among the side effects noted was a drop in systolic blood pressure of over $30 \mathrm{~mm} H$ in three patients. In two patients this was controlled by stopping the drip and running in about $500 \mathrm{ml} \mathrm{5 \%}$ dextrase in the course of half an hour. In the third patient the blood pressure had dropped to $90 / 60 \mathrm{~mm}$ $\mathrm{Hg}$ from an initial $126 / 80 \mathrm{~mm} \mathrm{Hg}$ and the drip was continued under close supervision. There was an associated tachycardia of 120 per minute. Within half an hour the blood pressure rose gradually to $110 / 70 \mathrm{~mm} \mathrm{Hg}$ and the drip was therefore not discontinued. All three patients were healthy, between the ages of 20 and 26 , para 2 or 3 , between 32 and 36 weeks' gestation, and with an initial cervical dilatation of 3 to $4 \mathrm{~cm}$.

Liggins et al. ${ }^{2}$ noted that the vasomotor side effects of salbutamol occur only at high doses. They used a Palmer pump to obtain an accurate, controlled dose. However, most clinical units throughout the world will only have recourse to simpler, inexpensive, but ess accurate standard intravenous infusion rets, and it seems therefore that while using this technique for arresting premature onset of labour a close check on the blood pressure is advisable at least for the first hour. Despite the associated fetal tachycardia ${ }^{2}$ the fetus appears in no way compromised, and certainly when the initial drop in blood pressure is not too great the drip can be continued under close supervision.

We wish to acknowledge the continuing help of Glaxo Holdings Ltd.-We are, etc.,

K. H. NG

D. K. SEN

Department of Obstetrics and Gynaecology,

niversity of Malaya,

1 Sen, D. K., and Ng, K. H., Medical fournal of Malaysia, 1974, 28. 191.

Malaysia, 1974, 28. 191.
Liggins, G. C., and Vaughan, G. S., Fournal of monvealth, 1973, 80, 29.

\section{Duration of Action of $\beta$-Adrenergic Blocking Drugs}

SIR,-Drs. P. D. Nigam and A. S. Malhotra (24 March 1973, p. 742) have reported a clinical study designed to evaluate the response of angina to pindolol. Their results suggested a carry-over effect that might be explained by a long duration of action of pindolol. Dr. S. G. Carruthers and others (21 April 1973, p. 177) presented data on the duration of action of some $\beta$-blocking drugs (alprenolol, practolol, and sotalol) and stated that more information was necessary to enable more accurate dosage schedules to be recommended. We recently supervised a study aimed at determining the oral antiarrhythmic response of sotalol (DL-4-(2isopropylamino-1-hydroxyethyl) methanesulphonanilide hydrochloride) and also administered ${ }^{3} \mathrm{H}$-sotalol $(100 \mu \mathrm{g})$ to two patients to determine its metabolic profile. Information is also available conoerning the distribution of sotalol in animals. ${ }^{1}$

Sixteen patients suffering from cardiac arrhythmias were given $100 \mathrm{mg}$ of sotalol,
$100 \mathrm{mg}$ of alprenolol, and placebo tablets four times a day for four suocessive weeks under double-blind cross-over conditions. The results indicated that sotalol had an anti-arrhythmic profile similar to those of other $\beta$-blocking drugs. There was no evidence of a carry-over effect.

Sotalol has a long duration of action and Dr. Carruthers and his colleagues have shown that maximum $\beta$-blockage is not obtained with $400 \mathrm{mg}$ of sotalol. This single dose level produces $11.8 \%$ protection against exercise-induced tachycardia 96 hours after administration. A single $100 \mathrm{mg}$ dose (that used four times a day in this study) provides $10.6 \%$ protection 24 hours after administration, and Svedmyr et al. ${ }^{2}$ have shown that after single oral doses of $40 \mathrm{mg}$ of sotalol and propranolol both drugs had the same $\beta$-blocking effect against isoprenaline-induced tachycardia four hours after administration. After 24 hours sotalol still showed $50-60 \%$ protection while propranolol had no effect at this time. If these responses were related to plasma levels it is possible that over a four-week treatment period there would be evidence of accumulation. Plasma samples were accordingly taken at two-weekly intervals and the results (range at two weeks $1.14-4.05 \mu \mathrm{g} / \mathrm{ml}$ and at four weeks $0 \cdot 83-2.47 \mu \mathrm{g} / \mathrm{ml}$ ) indicated that plarma sotalol levels did not increase duning treatment.

Tritiated sotalol (100 mg) was administered as a single dose to two patients and provided peak plasma levels of 0.1 and 0.065 $\mathrm{mg} / 100 \mathrm{ml}$ respectively $2-3$ hours after administration. The decay was biphasic-an initial rapid reduction to 0.067 and 0.043 $\mathrm{mg} / 100 \mathrm{ml}$ after $5 \frac{1}{3}$ hours and a slower reduction to 0.015 and $0.0075 \mathrm{mg} / 100 \mathrm{ml}$ after 24 hours. Administration of tritiated sotalol to $\operatorname{dogs}(1.5 \mathrm{mg} / \mathrm{kg}$ and $15 \mathrm{mg} / \mathrm{kg})$ and rats (5 $\mathrm{mg} / \mathrm{kg}$ and $50 \mathrm{mg} / \mathrm{kg}$ ) showed no evidence of storage in liver, kidney, heart, lung, brain, spleen, adrenals, or gonads. The amount of ${ }^{3} \mathrm{H}$-sotalol present in muscle and fat 24 hours after treatment was less than $1 \mu \mathrm{g} / \mathrm{g}$. In virro experiments showed that sotalol is not bound to plasma proteins and the red blood cells-the plasma partition coefficient is unity.

Clinical objective data showed that $100 \mathrm{mg}$ of sotalol four times a day for four weeks significantly reduced the incidence of arrhythmias and plasma analysis demonstrated that accumulation did not oocur. -We are, etc.,

EDWIN BESTERMAN C. MOCARTHY

St. Mary's Hospital

London W.2

Martin, L. E. Perconal communication, 1973.

Svedmyr, N., Jakobsson, B., and Malmberg, R.,

\section{Folic Acid Supplements for} Pregnant Epileptics

SIR,-Dr. Marion H. Hall's (22 June, p. 661) admirably concise account of anaemia in pregnancy raises two points which deserve comment. One is academic and merely a matter of setting the record straight-the attribution to us of the suggestion that the normal fall in serum folate in pregnancy is "principally" due to increased renal excretion of folate. Our paper ${ }^{1}$ indicated only that the increased excretion, if it oocurs in the presence of folate deficiency, could 
aggravate the situation; whether it plays any significant role in lowering the plasma level is very doubtful.

The second point is more important-the suggestion that epileptic women on anticonvulsant drugs should not be given folic acid supplements during pregnancy unless "megaloblastic anaemia actually occurs," because of a risk of increased fits. The clinical evidence for an increase in fits following folic acid supplements in epilepsy has been disputed. But on the other hand there seems no doubt that anticonvulsants can provoke a measure of folate deficiency, which may not necessarily develop into overt megaloblastic anaemia. The dilemma becomes particularly acute with anticonvulsant therapy duning pregnancy. The possibility of a lower fit threshold must be balanced against the potential hazands to mother and fetus of some insidious disturbance of folate metabolism. Until we know much more about the complex metabolic inter-relations of folate and anticonvulsant drugs, particularly in pregnancy, Dr. Hall's advice seems a little injudicious.-We are, etc.,

M. J. LANDON F. E. HYTTEN

M.R.C. Reproduction and Growth Unit,

Princess Mary Maternity Hospital,

Newcastle upon Tyne 1 Landon, M. J., and Hytten, F. E., fournal of

Obstetrics and Gynaecology
Commonwealth, 1971, 78, 769.

\section{Death during Dental Anaesthesia}

SIR,-Dr. J. G. Boume (16 March, p. 516) has undoubtedly done a useful service in drawing attention to the dangers of fainting in the dental chair. I have given between 400 and 800 dental anaesthetics annually, the great majority in the $45^{\circ}$ sitting position, for the past 30 years. In this time, however, I have only once observed a faint before or during anaesthesia, and this, as in Dr. W. N. Rollason's case (25 May, p. 444), occurred on venepuncture and before the injection of an intravenous anaesthetic. The occasional patient has, of course, shown a vasovagal response to a postoperative nausea or vomit, but none has proceeded to unconsciousness and all have responded promptly to treatment.

This experience prompts me to ask why I have been more fortunate than some others. It may be that the circumstances of private practice are, in some respects, more favourable than outpatient clinics. The patients generally know the dentist well and may also know me, the anaesthetist, perconally. The sessions are short, usually three to five cases, and by having them in the early morning the patients are not hanging about a large part of the day with nothing in their bellies. It is unusual for them to be kept longer than a few minutes in the waiting room. Consequently it is rare for them to come to op ration looking pale and frightened, and when they do extra care is taken.

In short, what strikes me most about these difficult cares is the presence of pathological fear. If this is protracted (and, maybe, aggravated by pain and toxic absorption) we have a situation in which the patient's adrenocortical response mechanism is exhausted before it is confronted with anaesthetic or surgical insults. This, I believe, is of greater significance than either the particular anaesthetic technique, or the agents used-provided of course that they are correctly applied-or indeed the exact position of the patient in the dental chair.

While not disputing the potential added safety of the horizontal position, therefore, I wonder whether stressing it is not putting the accent in the wrong place. Would it not be as well to teach (1) that greater efforts should be made to protect patients from the stresses which lead to a fainting reaction and (2) that pale and frightened patients are very special risk patients who need extra care in their management?-I am, etc.,

Stratford-upon-Avon

E. O. Evans

\section{Cremophor EL as a Diluent for Diazepam}

SIR,-Diazepam has proved a safe and reliable drug though there have been many reports of minor sequelae after intravenous administration. Pain during injection has been reported in $15 \%$ to $22 \%$ of patients ${ }^{12}$ and a $3.5 \%$ to $30 \%$ incidence of postoperative venous thrombosis or thrombophlebitis has been found. ${ }^{3}$ There seems to be no correlation between pain during injection and postoperative venous sequelae. ${ }^{3}$

Dilution of diazepam with water or saline reduces the incidence of these side effects ${ }^{4}$ but an emulsion of fine particles is produced. ${ }^{5}$ We have found that, if freshly prepared, these emulsions will clear when mixed with an equal volume of serum. However, if the emulsion is allowed to stand for a short time solid crystals which are insoluble in serum gradually form. It would therefore seem that the intravenous injection of such emulsions presents a potential hazard. Cremophor EL has the ability to take into solution a variety of agents which themselves are only sparingly soluble in water, a $20 \%$ solution being used in preparations of both propanidid and Althesin. We have found that when diazepam is diluted with a $1 \%$ solution of cremophor EL no clouding or precipitation occur. The mixture is stable for some time and it does not form a precipitate when added to serum. Though cremophor EL appears to be a safe organic solven $t^{6}$ possibly it may very occasionally be reponsible for adverse reactions in susceptible subjects. In view of this we are a present studying the use of a $10 \%$ mixture of ethanol in saline as an alternative diluent.

Over the past two years we have used $1 \%$ solution of cremophor EL in saline as a diluent for diazepam given intravenously in over 400 patients. Before use the cremophor solution was filtered, put into ampoules, and autoclaved: $8 \mathrm{ml}$ of the solution was used to dilute $2 \mathrm{ml}$ of diazepam, giving a mixture containing $1 \mathrm{mg} / \mathrm{ml}$. Use of this mixture has practically eliminated the incidence of pain during iniection, even when into small veins on the back of the hand. Pos operative venous thrombosis and thrombophlebitis occurred in fewer that $1 \%$ of patients.-We are, etc.,

G. W. Burton R. T. LENZ

Bristol Royal Infirmary

T. A. THOMAS

University Dental Hospital,

M. MIDDA

1 Brown, S. S., and Dundee, J. W., British fournal of Anaesthesia, 1968, 40, 108. McClish, A., Canadian Anaesthetists' Society
fournal, 1966, 13, 562.
3 Langdon, D. E., Harlan, J. R., and Bailey, R. L.,
fournal of the American Medical Association,
1973, 223, 184.
4 Hunter, A. R., and Bush, G. H., General
Anaesthesia for Dental Surgery, p. 95. Altrin-
cham, Sherratt, 1971.
5 Dundee, J. W., and Haslett, W. H. K., British
fournal of Anaesthesia, 1970, 42, 217
6 Savage, T. M., Foley, E. I., and Simpson, B. R.,
British fournal of Anaesthesia, 1973, 45, 515.

Flupenthixol Decanoate and Some Aggressive States

SIR,-There is no reference in the English medical literature to the use of flupenthixol in remote reactions. Because neuroleptic drugs as a group have sedative properties of a special order I gave flupenthixol decanoate to six patients in doses of 10-12 mg fortnightly by deep intramuscular injection. The patients all had a common factor-extremely low tolerance to frustration. Their reaction to this was either a sudden outburst of rage or the development of sullen hate with a later manifestation of aggression against the object that had induced the complex mood.

They all benefited with a marked reduction of the underlying anxiety and cessation of this form of aggression. There was an improvement in concentration, no lessening of drive, and no evidence of anergia. The relief occurred within three weeks of commencing treatment. No anticholinergic drugs were required. Naturally, they were happier people and their rapport with friends and family improved.

I lay no claim to having found a universal panacea for aggressive behaviour but the straws in the wind do seem to indicate that there is a place for the use of this drug or its oral form, flupenthixol dihydrochloride, outside the treatment of the schizophrenias. I would be very interested to hear if others using this drug have noted any like reaction. -I am, etc.,

Winwick Hospital,

P. M. O’Flanagan Warrington, Cheshire

\section{Measurement of Side Effects of Drugs}

SIR,-Drs. E. C. Huskisson and J. A. Wojtulewski (29 June, p. 698) suggest that when assessing the proportion of patients with side effects from drug therapy the interviewing doctor should not consult a check list. They found that direct questioning increases the number of positive responses in a group not receiving the treatment and reduces the number of positive responses to questions not on the check list.

They suggest that the doctor should ask, "Have you noticed any new symptoms which might be related to the treatment?" This method of collecting information suffers from a lack of standardization. The exact que tion asked may vary, and the "sympathetic" doctor receives more positive responses. The results thus obtained may not be reproduced by another observer, and may account for the wide variation in the prevalence of side effects reported in different publications. An example is given by methyldopa and sleepiness. In well-designed and conducted studies the proportion complaining of sleepiness while taking this drug varies between $12 \%{ }^{1}$ and $83 \% .^{2}$ Research workers investigating symptoms and side effects reauire to know the prevalence of these complaints in the general population 